\title{
Life Cycle Inventories of Metals and Methodological Aspects of Inventorying Material Resources in ecoinvent
}

\author{
Hans-Jörg Althaus* and Mischa Classen \\ EMPA, Swiss Federal Laboratories for Materials Testing and Research, Ueberlandstrasse 129, CH-8600 Duebendorf, Switzerland
}

* Corresponding author (hans-joerg.althaus@empa.ch)

DOI: http://dx.doi.org/10.1065/lca2004.11.181.5

\section{Abstract}

Goal, Scope and Background. The ecoinvent database provides harmonised generic life cycle inventories for metal production and processing. They can be used as background data for different LCA applications. The goal of this paper is to provide an overview of the metals inventoried in ecoinvent. Beside, some methodological background information is given. The focus lies on a new methodology developed to inventorying joint resources. The implementation is shown in a case study of the production of primary copper on a global average. The respective process is assessed with Eco-indicator 99 (H,A) to identify dominant impacts within the production chain.

Methods. In ecoinvent, a coupled production is inventoried in multi output unit processes. For database calculation, an allocation by economic revenue is applied. Elementary flows for resources, especially joint resources, include information on type and quality of the resources.

Results and Conclusion. With the presented method, the extraction of resources can be valuated based on the cost of restoration or the change in the future impact due to the extraction of a specific resource. The case study indicates, for copper / molybdenum production, that the mineral extraction is of minor importance compared to the metallurgical step according to the LCIA results. Air emissions of heavy metals are identified as main impacts. Also, the resource depletion shows a notable impact. The environmental impacts of metals from sulphidic ores, however, are underestimated by neglecting emissions from tailings for lack of reliable data.

Recommendation and Perspective. Impact assessment methods will have to be updated to account for different grades of ore. The ecoinvent database should be enlarged by more inventories of technically important metals and alloys, e.g. by gold, silver, solders, etc. for the electronics industry and by specific steel and aluminium alloys. Reliable composition data of sulphidic tailings and transfer coefficients for their disposal considering Acidic Rock Drainage (ARD) are to be developed as well.

Keywords: Copper; couple production; ecoinvent; LCI model; life cycle inventory; metal production; metals; resource depletion; Switzerland; tailings

\section{Introduction}

Life cycle inventory data for the production and processing of a great number of metals was developed and harmonised within the framework of the ecoinvent 2000 project (Frischknecht et al. 2004a). According to the high relevance of metals in almost all economic fields, these inventories were given a high priority.
The present paper describes the goal and scope of metal inventories in the ecoinvent database and provides an overview of its content with special focus on mining waste disposal. Furthermore, some important methodological aspects of inventorying metals are discussed. The focus in this part is on inventorying resources, especially joint resources. The aspects are shown on a case study of global copper production.

\section{Goal and Scope of Metals' $\mathrm{LCl}$ in ecoinvent}

For general information on goal and scope of the ecoinvent database, refer to Frischknecht et al. (2004a). The goal of the metal inventories in ecoinvent is to provide generic background data to be used in an LCA of products and processes. Ecoinvent datasets on metal production are not meant to be used directly to analyse the metal producing processes nor can ecoinvent data be used to compare similar alloys of the same metals. Like all ecoinvent data, the metal inventories relate to the common technology mix for the year 2000 and to Europe or Switzerland. Since metal markets are global, datasets for other regions are established to be used in the production mixes for Europe.

\subsection{Metals inventoried}

Cast iron and three types of steel (unalloyed, low alloyed and stainless steel $(\mathrm{Cr} / \mathrm{Ni} 18 / 8))$ are inventoried in ecoinvent. World average data for mining and beneficiation of iron ore, sinter and pellet production, and the metallurgical processes are inventoried. Blast furnace and basic oxygen furnace (BOF) processes are inventoried for primary steel production (converter steel), while secondary steel is produced by the electric arc furnace $(\mathrm{EAF})$ process. The comprehensive data is based on sources from industry, literature and physical dependencies.

Ecoinvent includes data for the primary aluminium production via Bayer-process and electrolysis, and for the secondary production from both new and old scrap.

World average data of bauxite mining is used while the rest of the aluminium production data relates to the European situation. The comprehensive data is based on sources mainly from industry.

The joint production of copper and molybdenum is described in more detail in the case study to this paper.

The primary nickel and ferronickel production is modelled for the global situation. Nickel is co-produced with copper 
from sulphidic ore and the model is made accordingly. Ferronickel, which is used as an alloy for steel, is produced from oxidic ores not yielding any usable co-products. For a lack of data, the secondary nickel production could not be inventoried. However, since most of the nickel is used in alloys, it is not recycled separately but with the alloyed steel. Data for major mass fluxes is based on a comprehensive study while data on emissions from processes and from waste is based on only a few literature sources.

The production of chromite, ferrochromium and metallic chromium in Europe is inventoried. Chromite ore is mined and beneficiated. It is used for the production of chromium, ferrochromium as well as chemicals and refractory materials. Ferrochromium is produced by direct reduction of chromite ore and used as an alloy for steel. Chromium is made by an aluminothermic process or by electrolysis, and mainly used for special, iron-free alloys (superalloys), e.g. for high-temperature exposed components in chemical and petrochemical industries. Since no chromium is recycled within the chromium industry, but directly to the foundries of the stainless steel industry, no secondary chromium is considered in this study. Data for major mass fluxes is based on a comprehensive study while data on emissions from processes and from waste is based on few literature sources.

The production of ferromanganese and the further processing to manganese is inventoried for the European situation. Ferromanganese is used for alloying steel while manganese is used for alloying aluminium or for direct use (e.g. sputtering). Only the primary production is inventoried because manganese is mainly used in alloys and recycled in them. Major mass fluxes for the ferromanganese production were available in a comprehensive study while data on manganese production and on emissions from processes and from waste is based on a few literature sources.

The primary production of the three platinum group metals (PGM) platinum, palladium and rhodium, is modelled as couple production with copper and nickel for South Africa and Russia. For the secondary production of PGM, the recycling process of automotive catalysts is modelled. Data for major mass fluxes is based on rather comprehensive sources from industry, while data on emissions from processes and from waste is based on a few literature sources.

The production of lead and zinc (co-production), tin and copper alloys is inventoried mainly based on theoretical models, similarity assumptions and estimations. Recycling is neglected.

Metal processing such as rolling, extrusion, drawing, coating and welding is inventoried in separate datasets which in combination with the metal models a metal sheet, section bar, wire, etc. Data is mainly based on IPPC (2001), theoretical models and similarity assumptions.

\section{Modelling Principles}

\subsection{System layout and boundaries}

Ecoinvent Data v1.1 contains inventory data for many technically important metals and metal processing operations. According to the general rules (Frischknecht et al. 2004a), the primary metals are as far as possible inventoried in unit processes for mining, beneficiation and metallurgy. The secondary metals are modelled by scrap collection, sorting and the recycling processes. For some of the metals, a mix of primary and secondary material is modelled using the share of secondary material in the production of the year 2000. The decision whether to use data of primary, secondary or the mix of the two depends on the goal and scope of the LCA to be conducted (Werner 2002, Werner 2003, Werner \& Richter 2000). For many metals from ores containing different usable metal fractions, co-production processes are modelled. Allocation is usually done by economic revenue. Resources are inventoried including information on their concentration and composition and allocated by mass to respect mass conservation.

\subsection{Modelling land use and infrastructure}

Land use is inventoried as land occupation and land transformation. The land use for mining and disposal of overburdens and tailings is inventoried directly within the mining and disposal process. The lowering of land above underground mines is not considered to affect the ecosystem quality. Thus, land use for underground mines is not inventoried. In most of the metal inventories, no restoration was assumed. For additional reclamation of the mine we suggest to model it based on the corresponding processes from bauxite or iron ore mining. Land use for the mine infrastructure (buildings, permanent roads, machines...) is inventoried in the infrastructure processes. Details on inventorying land use and infrastructure are given in Althaus et al. (2004b) and Frischknecht et al. (2004a).

\subsection{Modelling tailings and overburden disposal}

Mining produces considerable quantities of unwanted minerals since the desired metal occurs only in relatively low grades in the ore. These residues are referred to as overburdens (waste from mining) or tailings (waste from processing of ores) (IPPC 2002).

Overburdens are always assumed to be inert. If they are backfilled to the mines, they are considered as recycled and the cut-off rule is applied. If they are dumped on heaps, the land use of the dump site is inventoried in a special disposal process.

Tailings disposal is implemented in ecoinvent using specific disposal processes for different types of tailings:

1. The disposal of red mud from the aluminium hydroxide production is inventoried using a generic composition derived from literature (Altundogan et al. 2002, Anonymous 2001, McLaughlin et al. 1998, NPI 1999) and the model for the Swiss residual landfill (Doka 2003, Doka \& Hischier 2004). This model takes into account that the $\mathrm{pH}$ of red mud is high and that it will remain high for as long as emissions from the land fill are modelled (60,000 years).

2. Non-sulphidic tailings, e.g. from ferronickel, chromite or manganese beneficiation, are assumed to be chemically inert. Thus, the disposal of them is principally inventoried like the disposal of overburdens. However, the land use for disposal of tailings is higher than for disposal of overburdens. 


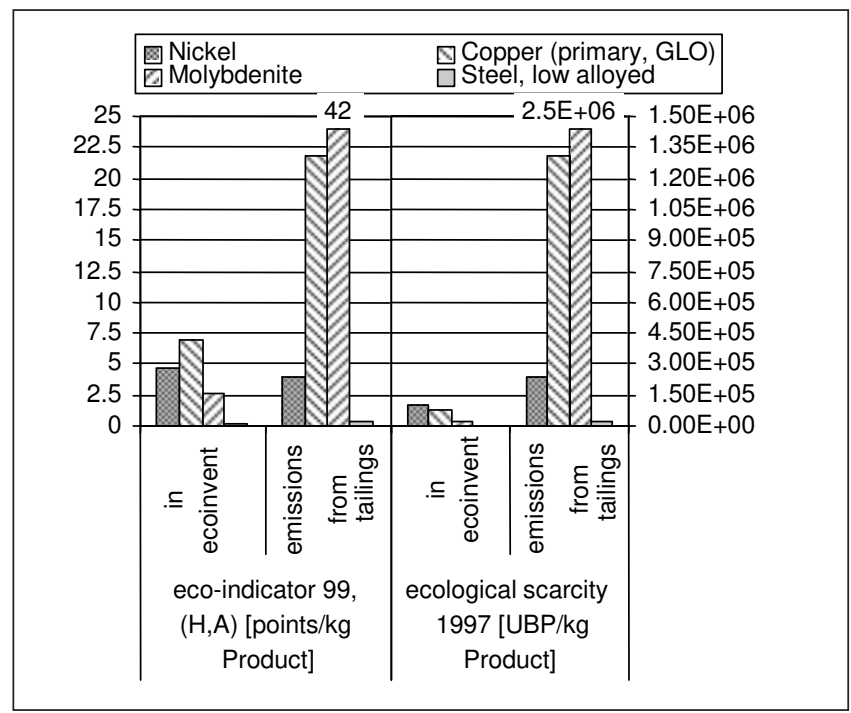

Fig. 1: Impacts from metal production in ecoinvent (neglecting emissions from sulphidic tailings deposition) and from crudely modelled emissions from the deposition of the sulphidic tailings of this production

3. Sulphidic tailings as those of e.g. copper, nickel, PGM (platinum group metals), lead or zinc tend to Acid Rock Drainage (ARD), a process in which sulphur oxidises in the presence of metal, water and oxygen to sulphuric acid. This process is often promoted by bacterial activity and lasts as long as sulphur is present in the material. The sulphur serves as a source of energy for bacteria like the autotrophic Thiobacillus ferrooxidans. Its metabolism is a most important driver in the ARD. ARD accelerates the weathering due to the acidic environment with a $\mathrm{pH}$ of 2.5 to 3 in the saturated phase and metals are washed out into the ground water over a very long time period (Lottermoser 2003). Despite the phenomenon of ARD, the disposal of sulphidic tailings in ecoinvent comprises only land use and land transformation. This is due to a lack of reliable data for the modelling of tailing disposal. The composition of tailings is very variable depending on the mine and there is only very few data available from specific sites. Also, the modelling of transfer coefficients for the heavy metals in the tailings from the disposal site to the ground water would require many site specific information as e.g. the rainfall at or geological information of the disposal site. To estimate the potential scale of the impacts of tailings emissions a hypothetical average composition for generic sulphidic tailings was derived and the emissions from its disposal were crudely modelled (Althaus et al. 2004a, Non Ferrous Metal Winning Auxiliary Processes). This data can be used to include emissions from tailings disposals into inventories of metals from sulphidic ores. Fig. 1 shows the impacts of the production of different metals neglecting the emissions from tailings deposition and the impacts from the corresponding tailings deposition according to this data. Even though the relevance for the sulphidic metals and also for low alloyed steel (containing $1 \%$ of $\mathrm{Mo}$ ) is high, the high uncertainty led to the decision to exclude emissions arising from ARD in this version of ecoinvent data completely and to develop more reliable models for a later version.

\subsection{Inventorying material resources in ecoinvent}

A new methodology of inventorying material resources and especially joint metal resources complying with the commonly used impact assessment methods is proposed in ecoinvent. Impact assessment methods usually aggregate and assess resources based on one of the following criteria (Guinèe et al. 2001):

- mass

- reserves

- cost of restoration or substitution of the resource

- change in the future impact of the extraction due to the need to extract from lower grade deposits

Inventory data for metal ores on the other hand usually relate either to the amount of a specific metal in the ore or to the amount of a specific metal-containing mineral in the ore. Such inventory data strictly allow only simple assessments based on mass and reserves since the other criteria depend on the type and quality of the deposit from which the resource is extracted. Therefore information on the concentration of the metal in the ore and on the amount of overburden is needed. As we have mentioned above, many metal ores contain several metals that are co-produced. These joint resources need to be represented in inventories bearing information on all extracted elements or minerals present in the ore to allow for an assessment.

The method of inventorying abiotic resources developed for ecoinvent allows the assessment of single or joint resources based on all of the above mentioned criteria. The elementary flow in ecoinvent relates to the element or mineral in focus and delivers information on its content in the ore and on the content of other economically valuable elements or minerals in the crude ore. The depletion of a joint sulphidic copper and molybdenum ore, for example, is inventoried as extraction of 'Copper, $0.99 \%$ in sulfide, $\mathrm{Cu} 0.36 \%$ and $\mathrm{Mo}$ $8.2 \mathrm{E}-3 \%$ in crude ore, in ground' and 'Molybdenum, $0.022 \%$ in sulphide, $\mathrm{Mo} 8.2 \mathrm{E}-3 \%$ and $\mathrm{Cu} 0.22 \%$ in crude ore, in ground' (Table 1). The concentration of copper in the sulphide is $0.99 \%$. Since there are minerals not containing copper in the crude ore, the copper concentration in the crude ore is only $0.36 \%$. The elementary flow, however, relates only to the first mentioned metal. Thus, the extraction of $1 \mathrm{~kg}$ 'Copper, ... in ground' stands for the extraction of $1 \mathrm{~kg}$ copper contained in $277.8 \mathrm{~kg}$ of crude ore. The yield of the mining and beneficiation process is $84 \%$ and the extraction of the copper resource is completely allocated to the copper concentrate produced. Thus, $1 \mathrm{~kg}$ copper concentrate (con-

Table 1: Resource demand and products as modelled in the joint copper molybdenum production

\begin{tabular}{|c|c|c|c|c|}
\hline & \multicolumn{2}{|c|}{ Allocation to } \\
\hline Input & \multicolumn{2}{|c|}{ Amount } & $\mathrm{Cu}$ & Mo \\
\hline $\begin{array}{l}\text { Copper, } 0.99 \% \text { in sulfide, } \\
\text { Cu } 0.36 \% \text { and Mo } 8.2 E-3 \% \\
\text { in crude ore, in ground }\end{array}$ & 0.36 & $\mathrm{~kg}$ & 100 & 0 \\
\hline $\begin{array}{l}\text { Molybdenum, } 0.022 \% \text { in sulfide, } \\
\text { Mo } 8.2 \mathrm{E}-3 \% \text { and } \mathrm{Cu} 0.36 \% \\
\text { in crude ore, in ground }\end{array}$ & 0.0078 & $\mathrm{~kg}$ & 64 & 36 \\
\hline \multicolumn{5}{|l|}{ Output } \\
\hline Cu concentrate $(29.7 \% \mathrm{Cu})$ & 1.00 & $\mathrm{~kg}$ & 100 & 0 \\
\hline Mo concentrate (55\% Mo) & 0.0041 & $\mathrm{~kg}$ & 0 & 100 \\
\hline
\end{tabular}


taining $0.297 \mathrm{~kg}$ copper) is won from $0.36 \mathrm{~kg}$ 'Copper, $0.99 \%$ in sulfide, $\mathrm{Cu} 0.36 \%$ and Mo $8.2 \mathrm{E}-3 \%$ in crude ore, in ground'. The extraction of the molybdenum resource is allocated to the copper $(64 \%)$ and the molybdenum $(36 \%)$ produced because, on a global scale, only $36 \%$ of the molybdenum mined together with copper is actually won while $64 \%$ are disposed of as an overburden. The yield for production of molybdenum concentrate is $80 \%$. Thus, of the $7.8 \mathrm{~g}$ of Mo mined together with $0.36 \mathrm{~kg}$ copper only $2.8 \mathrm{~g}$ is processed of which $2.3 \mathrm{~g}$ is finally contained in the molybdenum concentrate. The molybdenum mined but not extracted from the ore is allocated to the copper produced. These elementary flows allow an assessment of all abiotic resources based on any of the existing impact assessment methods. However, care has to be taken to not double count joint resources.

\section{Case Study: Joint Production of Copper and Molybdenum}

In the last decade, a broad discussion about environmental issues arose in the metal winning industry. Life cycle impact assessment (LCIA) is able to analyse the entire production system towards impacts. It is therefore a more integrated approach than the discussions on specific technical optimisation issues.

This case study shows the implementation of the global copper production mix copper, primary, at refinery in ecoinvent. It is taken as an example to identify dominant impacts in the metal production chain. The inventory data from ecoinvent v1.1 covers all the processes from extraction, beneficiation and tailings management to hydro- and pyrometallurgical processes including land use and transformation, the disposal of slags as well as the co-production of sulphuric acid from the off-gas. As a result, the main impacts within the production chain on a global average are discussed according to the Eco-indicator 99 (H,A) valuation method $^{1}$ (Goedkoop \& Spriensma 2000).

1 This method of impact assessment values from a hierarchist viewpoint.

\subsection{Inventories for copper production and copper consumption}

The copper production is represented in ecoinvent by a set of inventories representing the different deposits and the specific technologies applied in different regions of the world (Krauss et al. 1999). The regions distinguished are North America (RNA), Latin America (RLA), Europe (RER), Asia (RAS), Australia / Indonesia (ID) and a global weighted mix (GLO). The technology mix associated with the resulting six regional inventories is displayed in Table 2. The regional inventories of primary copper production consist of the pyrometallurgical processes, the respective specific exploitation and the respective share in hydrometallurgical produced copper as showed in Fig. 2. Note, that the regional inventory for exploitation copper ore in ecoinvent is a multi-output process with the products copper, concentrate, at beneficiation and molybdenum, molybdenite concentrate, couple production $\mathrm{Cu}$.

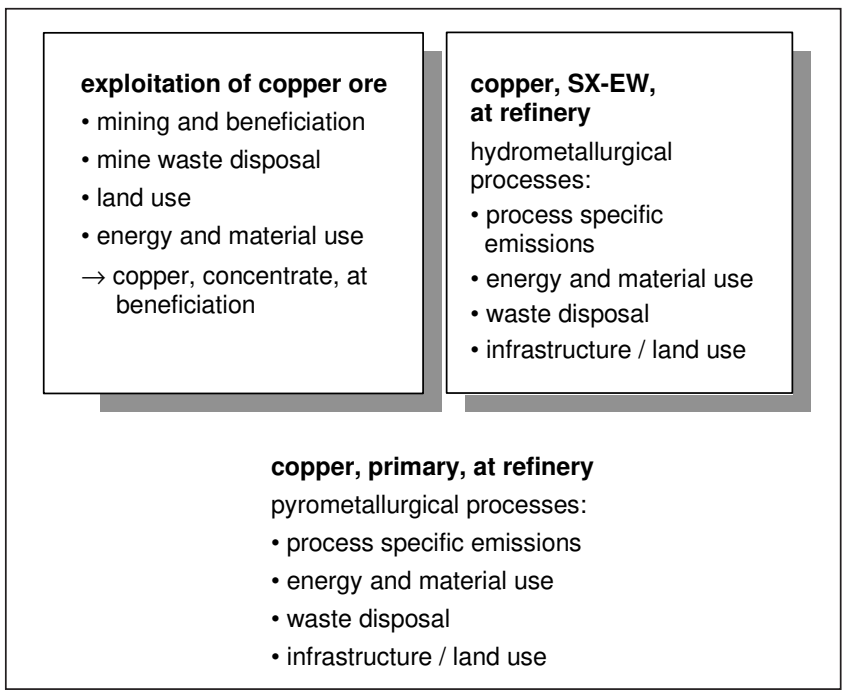

Fig. 2: Layout and system boundary of the inventory of copper, primary, at refinery. This inventory describes the winning of copper on global average from cradle to the refinery's gate and it refers to the inventories of copper, concentrate, at beneficiation and the hydrometallurgical copper, sx-ew, at refinery

Table 2: Technology mix reflected in the copper inventories of the different regions (Krauss et al. 1999)

\begin{tabular}{|c|c|c|c|c|c|c|}
\hline $\begin{array}{l}\text { Production in MMT } \\
\left(10^{6} \text { metric tonnes, } 1994\right)\end{array}$ & North America & South America & Europe & GUS / Asia & $\begin{array}{c}\text { Indonesia / } \\
\text { Australia }\end{array}$ & World \\
\hline Region in ecoinvent & RNA & RLA & RER & RAS & ID & GLO \\
\hline Total copper prod. & \multicolumn{2}{|c|}{3840} & 1185 & 2915 & 295 & 8760 \\
\hline Reverberatory furnace ${ }^{\text {a) }}$ & \multicolumn{2}{|c|}{895} & 70 & 595 & 90 & 2010 \\
\hline Electric furnace ${ }^{b)}$ & \multicolumn{2}{|c|}{30} & 80 & 170 & & 425 \\
\hline Outokumpu ${ }^{\text {b) }}$ & \multicolumn{2}{|c|}{995} & 775 & 1320 & 40 & 3160 \\
\hline Inco b) & \multicolumn{2}{|c|}{350} & & 90 & & 440 \\
\hline Kivcet $^{\mathrm{b})}$ & & & & 40 & & 40 \\
\hline Mitsubishi ${ }^{b)}$ & \multicolumn{2}{|c|}{100} & & 200 & & 300 \\
\hline Noranda ${ }^{b)}$ & \multicolumn{2}{|c|}{180} & & & 40 & 220 \\
\hline Teniente ${ }^{b)}$ & \multicolumn{2}{|c|}{415} & & & & 415 \\
\hline Vanyukov ${ }^{b)}$ & & & & 155 & & 155 \\
\hline Other $^{\text {a) }}$ & \multicolumn{2}{|c|}{200} & 200 & 40 & 90 & 530 \\
\hline SX-EW ${ }^{c)}$ & \multicolumn{2}{|c|}{$675(17.6 \%)$} & & & $25(8.8 \%)$ & $800(9.4 \%)$ \\
\hline total recorded & \multicolumn{2}{|c|}{3840} & 1125 & 2610 & 285 & 8495 \\
\hline Abatement $\mathrm{SO}_{2}$ & $50 \%$ & $50 \%$ & $95 \%$ & $20 \%$ & $20 \%$ & $45 \%$ \\
\hline $\begin{array}{l}\text { a) furnace type with moderat } \\
\text { b) furnace type with moderat } \\
\text { c) furnace type with little SO }\end{array}$ & \multicolumn{2}{|c|}{ b) furnace type with moderate $\mathrm{SO}_{2}$-emission $(0.15 \mathrm{t} / \mathrm{t}$ ) (Ayres et al. (2002)) } & & & & \\
\hline
\end{tabular}


The LCA practitioner usually is not so interested in the production inventories, but in the inventory representing the actual composition and origin of the material used. Such an inventory consists of a mix of different production inventories and a certain transportation service; it is therefore very contextual and varies from application to application. Nevertheless a consumption mix copper, at regional storage is implemented in ecoinvent. This inventory represents the situation for Germany in 1994 and stands for the generic copper consumption in European countries. Since this supply mix is a specific blend of different imported primary material, primary material from imported concentrate, primary material from domestic production and secondary material from old and new scrap, it should be used carefully and adapted to the actual study by assembling production inventories and transport service accordingly The secondary material in the consumer mix originates from old and new scrap (Bertram et al. 2002). New scrap is used directly in the foundries, whereas old scrap is inventoried as copper, secondary, at refinery. In this process the old scrap enters the pyrolytical production chain as raw material where it is converted together with $10 \%$ of blister copper (Rentz et al. 1999). The collection and pre-treatment of old and new scrap is inventoried in copper, secondary, at beneficiation.

\subsection{Resource intensity of copper production}

Copper can be found in sulphidic minerals, such as chalcopyrite $\left(\mathrm{CuFeS}_{2}\right)$, chalcocite $\left(\mathrm{Cu}_{2} \mathrm{~S}\right)$, bornite $\left(\mathrm{Cu}_{5} \mathrm{FeS}_{4}\right)$ and enargite $\left(\mathrm{Cu}_{3} \mathrm{AsS}_{4}\right)$. An other resource type is oxidic mineral, which is the weathered products of sulphide minerals, especially malachite $\left(\mathrm{CuCO}_{3} \cdot \mathrm{Cu}(\mathrm{OH})_{2}\right)$, azurite $\left(2 \mathrm{CuCO}_{3}\right.$. $\left.\mathrm{Cu}(\mathrm{OH})_{2}\right)$, cuprite $\left(\mathrm{Cu}_{2} \mathrm{O}\right)$ and chrysacolla $\left(\mathrm{CuSiO}_{3} \cdot 2 \mathrm{H}_{2} \mathrm{O}\right)$. In the beginning of the $20^{\text {th }}$ century in the U.S., the copper ore mined had grades of $3.4 \%{ }^{2}$, it was mined entirely underground. Nowadays, the grades have fallen in a global average below 1\% (Ayres et al. 2003). Worldwide 70\% of the copper production originates from open cut operations. Krauss et al. (1999) estimate that hydometallurgical techniques (Solvent-Extraction / Electrowinning, SX-EW) contribute to $10 \%$ of the global production. The overall yield for pyrolytical production based on sulphidic ore averages $81 \%$ on a global scale, whereas the SX-EW shows a yield of $70 \%$. Land use of copper mines has been thoroughly studied in recent years. Martens et al. (2002) studied a large number of mining sites and estimated the total land use to be $0.02 \mathrm{~m}^{2}$ per tonne ore mined. The results of these investigations have been used in ecoinvent.

The worked sulphidic ores of copper deposits often contain molybdenum as molybdenite $\left(\mathrm{MoS}_{2}\right)$. Almost half of the globally produced molybdenum originates from such deposits where molybdenum and copper jointly occur. Only at the stage of beneficiation the extracted ore is divided in copper and molybdenite concentrate. Therefore, the mining and beneficiation stages are modelled in ecoinvent as multi-output process, in which the coupled resources are allocated to the coupled products by mass. All other exchanges in this

${ }^{2}$ All percentages by weight process are allocated by economic revenue (see 3.4 Inventorying Material Resources in ecoinvent). This allocation rule, taking advantage of the separately modelled resources, decouples the two products from each other. Molybdenite concentrate receives a portion of the inventory from the coupled multi-output process and enters the production chain of molybdenum. In the copper production chain, it is no longer of importance.

\subsection{Mining and beneficiation}

Today only $30 \%$ of the copper is mined underground - the rest is mined in open pits with very large equipment. The resulting economies of scale make lower grade ores workable. Globally, 90\%-95\% of copper is extracted from sulphide minerals. On average, one tonne of sulphur is extracted with each tonne of copper. The oxide ores account for $5 \%$ $10 \%$ of the global copper production. An exact estimation is not easily possible due to time lags resulting form extraction techniques and the variety of used resources (Krauss et al. 1999). Since ecoinvent uses mining data of sulphidic ores as a proxy for mining of oxidic ores, the oxidic resource is represented by the elementary flow for sulphidic copper ore. Dust emissions from extraction and ore handling are inventoried with an average ore composition and as particulate matter (PM) according to Frischknecht et al. (2004b), while the distribution of size ranges and load are based on literature (NPI 2001).

After mining, the ore is ground. The metal bearing particles are separated from unwanted minerals by the means of magnetic separation. In a flotation step, the gangue is removed from the sulphidic ore. Several organic chemicals are added to enhance the separation performance. In some cases cyanide is used as a depressant for pyrite. The resulting slurry usually is led to tailing heaps or ponds. The resulting copper concentrates contain around $30 \% \mathrm{Cu}$. Molybdenite concentrate is further purified and exits the process with a concentration of 90-95\% molybdenum disulphide.

\subsection{Pyro- and hydrometallurgical production}

In the copper production there are two distinct metallurgical processes, which pose different demands to the concentrate processed. Whereas the sulphidic ores are processed by pyrometallurgical techniques, oxide ores and supergene sulphide ores (i.e. ores not containing iron) can be recovered most easily by hydrometallurgical techniques. The hydrometallurgical process wins copper by electrolytic means from an electrolyte rich in dissolved copper. The electrolyte is obtained by leaching the raw ore for considerable time spans; therefore, no further beneficiation of the ore is required. The hydrometallurgical process is only applicable to oxide ore, sulphides have to be roasted prior to leaching. In the course of the metallurgical step, sulphur present in the ore is oxidised to $\mathrm{SO}_{2}$.

In ecoinvent, the inventories of primary copper production consist of a mix of production processes reflecting the specific technologies in different world regions (see Table 2). The calcination of previously added lime releases $0.44 \mathrm{~kg}$ 
$\mathrm{CO}_{2}$ per tonne lime. Depending on the technology mix, the $\mathrm{SO}_{2}$-emissions after abatement range from $36 \mathrm{~kg} / \mathrm{t} \mathrm{Cu}$ for European smelter to $1296 \mathrm{~kg} / \mathrm{t} \mathrm{Cu}$ for Indonesian smelter (Ayres et al. 2003, Krauss et al. 1999). The abatement efficiency for $\mathrm{SO}_{2}$ is likely to be higher for newer smelting facilities due to technological improvement and stricter legislation. The sulphur dioxide retained exits the system as sulphuric acid with zero burden (cut-off approach). In the sense of a system expansion, the acid production substitutes $\mathrm{H}_{2} \mathrm{SO}_{4}$-use at other points in the production chain, i.e. the ore leaching for hydrometallurgical winning.

\section{Results and Discussion}

The following part discusses the results of the individual impacts assessed with the Eco-indicator 99 (H,A). The processes considered correspond to the production of one kilogram primary copper on a global average, as it is discussed in the previous sections of this paper. This process is represented in ecoinvent with the inventory of copper, primary, at refinery $(G L O)$.

Contributions of individual impacts are shown in Fig. 3. The values in this figure are grouped according to the subprocesses 'Concentrate' (mining and beneficiation of sulphidic ore), 'Primary copper' (pyrometallurgical step) and 'SX-EW' (mining of oxidic ore and hydrometallurgical process) in three columns. These columns add up to the respective contribution of the sub-process. The last column labelled with 'Total' summarises impacts from different sub-processes. The values in the last line indicate the remaining impacts, adding up to a total of $0.42 \%$ of the impacts that are not covered by this representation.
The most important impacts stem from the pyrometallurgical step in the form of emissions of heavy metals to air. These emissions total $55 \%$ of the total assessed impact. The emissions of sulphur dioxide arising from smelting are assessed to be much smaller $(8.8 \%)$. The assessment with other methods can alter this result. Using the method of ecological scarcity (Swiss Ecopoints, UBP), the result is shifted towards an increased importance of the $\mathrm{SO}_{2}$-emissions compared to heavy metal emissions to air. However, the highest potential for improvement lies in the abatement technology of pyrolytical processes. The impacts resulting from fuel use and its preparation, from lime addition and finally slag disposal are of minor importance, contributing to less than one percent. Within the mining and beneficiation step, the dust emissions from ore handling as fine particular matter $\left(\mathrm{PM}_{10}\right.$ and beyond) and, finally, the uses of the resource itself are considered to yield the most important impacts. Within the used impact assessment, particulate matter from mineral sources is valued equal to that from combustion. Since dust from mineral sources probably has a lower impact to human health than soot, for example, this valuation seems questionable and the weight of dust emission in this study might have to be relativised. Blasting (including explosive manufacturing and blast fumes) and maintenance of the mill (in the form of chromium steel consumption due to abrasion) are also noteworthy. Tailings disposal from sulphidic and oxidic ores are assessed to be of minor importance in the overall picture. This, however, is probably due to the data gap for the emissions from sulphidic tailings disposal. Post-consumer secondary copper from European smelter as represented in ecoinvent v1.1 with copper, secondary, at refinery $(R E R)$ is assessed with only $9.3 \%$ compared to the primary copper production on a global average.

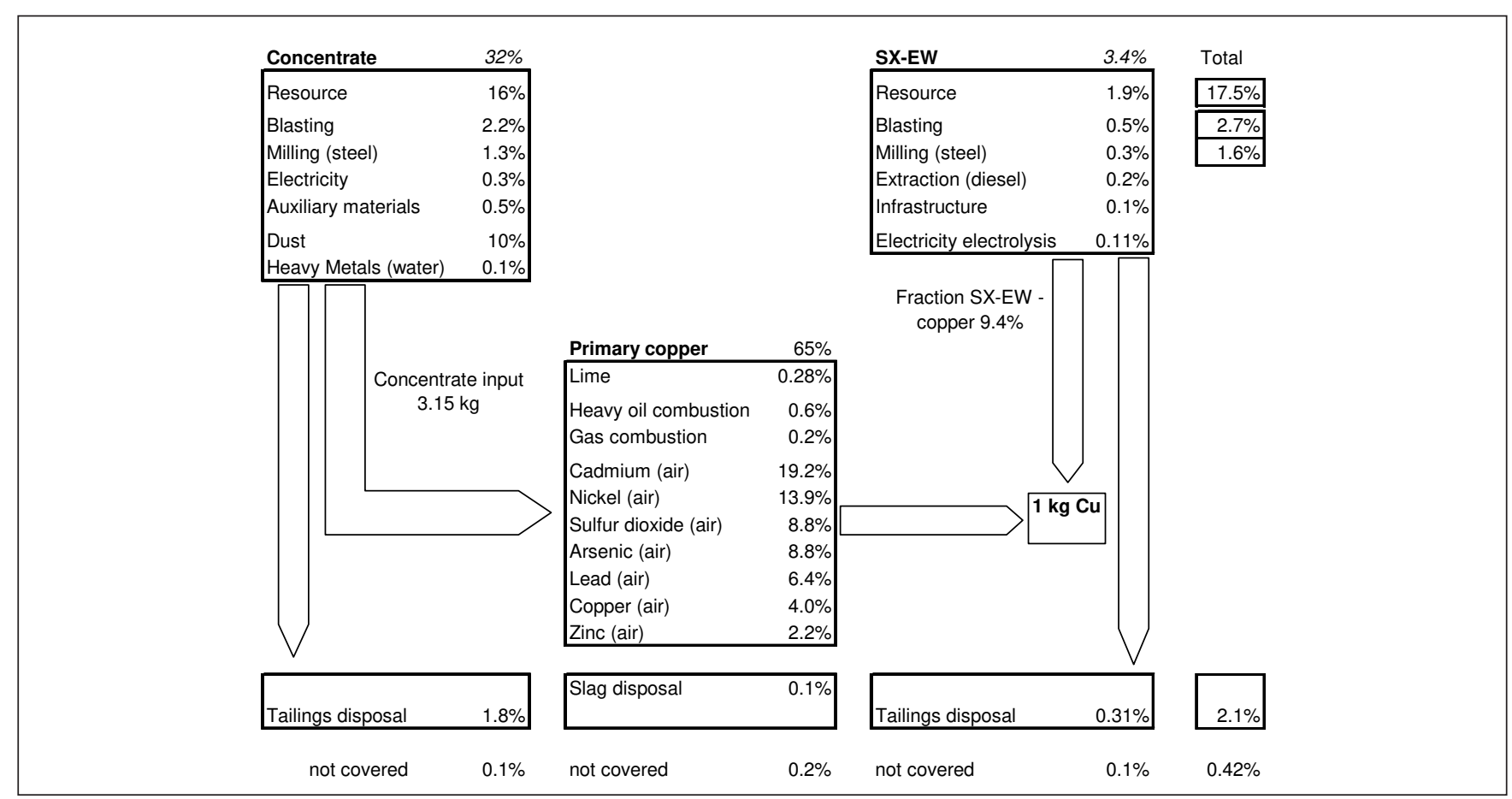

Fig. 3: Contributions of individual impacts within the primary copper production according to the damage-oriented valuation method Eco-indicator 99 $(\mathrm{H}, \mathrm{A})$. Elementary flows like emissions into air in the dataset for concentrate extraction or primary copper smelting represent direct process-specific emissions; emissions from combustion are stated separately 


\section{Conclusion}

The new methodology of inventorying material resources allows for specific impact assessment according to the resource quality and for dealing with jointly occurring resources in a consistent way. While the copper-molybdenum ore is extracted in a single process, the resulting concentrates enter two different production chains taking along its share in the burden from mineral extraction.

In the assessment of the global primary copper production with Eco-indicator 99 (H,A), the extraction of the mineral plays a minor role compared to the metallurgical step. Impacts from tailings management within the extraction itself are not assessed to be the main issue. However, the inclusion of emissions taking place from site closure on to the distant future indicates considerable additional impacts (see Fig. 1). Further research in the field of long-term emissions of disposal sites will lead to a better understanding of that complex subject and might lead to a reconsideration of the impacts of tailing sites.

The way how the use of secondary material is modelled in ecoinvent has a relevant influence on the assessment, since impacts of primary copper production exceed the impacts of secondary material by one order of magnitude. The cut off approach has been applied consistently in ecoinvent. However, if used consistently, the value-corrected substitution approach (Werner 2003) may be an alternative solution to model the copper production, especially in consequential LCA. The findings stress the role of resource depletion in the case of copper and its reuse in subsequent product life cycles. This sustains a vision of anthropogenic material flows that are almost self-sufficient by achieving a high recycling quota, substituting only that minimal amount of material that is dissipatively lost for further use (Rechberger \& Graedel 2002). Achieving this goal requires optimal product design.

\section{References}

Althaus H-J, Blaser S, Classen M, Jungbluth N (2004a): Life Cycle Inventories of Metals. Final report ecoinvent 2000 No. 10. EMPA Dübendorf, Swiss Centre for Life Cycle Inventories $<\underline{\mathrm{http}: / / \mathrm{www}}$. ecoinvent.ch>, Dübendorf, $\mathrm{CH}$

Althaus H-J, Kellenberger D, Doka G, Künniger T (2004b) Life Cycle Inventories of Building Materials and Methodological Aspects of Inventorying Infrastructure. Int J LCA 10 (1) \#\#-\#\#<DOI: http://dx.doi.org/10.1065/lca2004.11.181.4>

Altundogan HS, Altundogan S, Tümen F, Bildik M (2002): Arsenic adsorption from aqueous solutions by activated red mud. Waste Management 22, 357-363. Online-Version $<$ http://www.environmentalcenter.com/magazine/elsevier/waste/art11.pdf>

Anonymous (2001) Local Vegetable Fibres + Industrial and Mineral Wastes for Composite Materials. Building Materials \& Technology Promotion Council BMTPC of the Ministry of Urban Development and Poverty Alleviation, New Delhi. Online-Version $<$ http://www.bmtpc.org/fibre.pdf $>$

Ayres RU, Ayres LW, Råde I (2003): The Life Cycle of Copper, its Co-Products and Byproducts. Eco-efficiency in industry and science Vol. 13, Kluwer Academic, Dordrecht, NL

Bertram M, Graedel TE, Rechberger H, Spatari S (2002): The contemporary European copper cycle: Waste management subsystem. Ecological Economics 42, 43-57

Doka G (2003): Life Cycle Inventories of Waste Treatment Services. Final report ecoinvent 2000 No. 13. EMPA St. Gallen, Swiss Centre for Life Cycle Inventories $<$ http://www.ecoinvent.ch $>$, Dübendorf, $\mathrm{CH}$
Doka G, Hischier R (2004): Waste Treatment in Switzerland and Assessment of Long-Term Emissions. Int J LCA 10 (1) \#\#-\#\# <DOI: http://dx.doi.org/10.1065/lca2004.11.181.9>

Frischknecht R, Jungbluth N, Althaus H-J, Doka G, Dones R, Hellweg S, Hischier R, Nemecek T, Rebitzer G, Spielmann M (2004a): Survey of and Methodological Framework for the ecoinvent Database. Int J LCA 10 (1) \#\#-\#\# <DOI: http://dx.doi.org/10.1065/ lca2004.11.181.1>

Frischknecht R, Jungbluth N, Althaus H-J, Doka G, Dones R, Hischier R, Hellweg S, Nemecek T, Rebitzer G, Spielmann M (2004b): Overview and Methodology. Final report ecoinvent 2000 No. 1. Swiss Centre for Life Cycle Inventories $<$ http://www.ecoinvent.ch $>$, Dübendorf, $\mathrm{CH}$

Goedkoop M, Spriensma R (2000): The Eco-indicator 99, A Damage Oriented Method for Life Cycle Impact Assessment, Methodology Report, 2nd Ed. Pré Consultants, Amersfoort, NL

Guinèe JB (final editor), Gorrée M, Heijungs R, Huppes G, Kleijn R, de Koning A, van Oers L, Wegener Sleeswijk A, Suh S, Udo de Haes HA, de Bruijn H, van Duin R, Huijbregts MAJ, Lindeijer E, Roorda AAH, Weidema BP (2001): Life cycle assessment. An operational guide to the ISO standards, Part 3: Scientific Background. Ministry of Housing, Spatial Planning and Environment (VROM) and Centre of Environmental Science (CML), Den Haag and Leiden, NL

IPPC (2001): Integrated Pollution Prevention and Control (IPPC); Reference Document on Best Available Techniques in the Ferrous Metals Processing Industry. Retrieved 29.01.2003 from <http:// www.jrc.es/pub/english.cgi/0/733169>

IPPC (2002): Integrated Pollution Prevention and Control (IPPC). Draft Reference Document on Best Available Techniques for Management of Tailings and Waste-Rock in Mining Activities. Retrieved 15.01.2003 from <http://www.jrc.es/pub/english.cgi/0/733169>

Krauss U, Wagner H, Mori G (1999): Stoffmengenflüsse und Energiebedarf bei der Gewinnung ausgewählter mineralischer Rohstoffe; Teilstudie Kupfer. Geologisches Jahrbuch Sonderheft 9. Bundesanstalt für Geowissenschaften und Rohstoffe, Hannover, Germany

Lottermoser BG (2003): Mine wastes characterization, treatment, and environmental impacts. Springer Berlin, Germany

Martens PN, Ruhrberg M, Mistry M (2002): Flächeninanspruchnahme des Kupfererzberbaus. Erzmetall 55 (5/6) 287-293

McLaughlin MJ, Maier NA, Correll RL, Smart MK, Grant CD (1998): In-situ immobilisation techniques to remediate cadmium-contaminated agricultural soils. Contaminated Soil '98. Proceedings of the Sixth International FZK/TNO, London 453-460. Online-Version $<$ http://www.sardi.sa.gov.au/pages/horticulture/potato/insitu. htm:sectID $=319 \&$ tempID $=152>$

NPI (1999): Emission Estimation Technique Manual for Alumina Refining. National Pollutant Inventory. Environment Australia. OnlineVersion $<\underline{\text { http://www.npi.gov.au/handbooks/approved handbooks/ }}$ pubs/falref.pdf $>$

NPI (2001): Emission Estimation Technique Manual for Mining. National Pollution Inventory. Environment Australia. Online-Version $<$ http://www.npi.gov.au/>

Rentz O, Krippner M, Hähre S, Schultmann F (1999): Report on Best Available Techniques (BAT) in Copper Production. DeutschFranzösisches Institut für Umweltforschung (DFIU) and University of Karlsruhe (TH), Karlsruhe, Germany

Werner F (2002): Ambiguities in Decision-oriented Life Cycle Inventories: The Role of Mental Models. Int J LCA 7 (6) 330-338

Werner F (2003) Ambiguities in Decision-Oriented Life Cycle Inventories: The Role of Mental Models and Values. Diss. 14'750 Eidg. Technische Hochschule (ETH), Zürich, CH

Werner F, Richter K (2000) Economic Allocation in LCA: A Case Study about Aluminium Window Frames. Int J LCA 5 (2) 79-83

Received: August 16th, 2004

Accepted: November 4th, 2004 OnlineFirst: November 5th, 2004 